\title{
ROLE OF GLYCINE IN PROTECTING PECTINOPHORA GOSSYPIELLA (SAUND.) AGAINST STRONG PROTEIN- DENATURING ACTIVITY OF PHENOLIC COMPOUNDS IN COTTON PLANTS
}

Dina A. Ahmed ${ }^{(1)}$; El-Sharkawy, Manal A.A ${ }^{(1)}$; K.A. Hassan ${ }^{(1)}$ and Souad A. Shairra ${ }^{(2)}$ (1)Bollworm Dept., Plant Protection Research Institute, ARC, Dokki, Giza-Egypt.

(2)Biological Control Dept., Plant Protection Research Institute, ARC, Dokki, Giza-Egypt.

\begin{abstract}
To test the possibility that the free glycine has a role related to the resistance of the pink bollworm larvae to phenolic compounds (PCs), newly hatched larvae were fed on artificial diets containing different concentrations of the selected two PCs (pyrocatechol and resorcinol). Data indicated that the PCs have a great efficacy against pink bollworm larvae. Mortality percentages had a positive relationship with both the concentration and the period after treatment $(r=0.72 \pm 0.13)$. Based on the $\mathrm{LC}_{50}$ values, pyrochatechol was the most potent extract after two hours of treatment (toxicity index $(\mathrm{Ti})=100.0 \%$ ). Two days after treatment, resorcinol became the most effective extract $(\mathrm{Ti}=100.0 \%)$, as it had the lowest $\mathrm{LC}_{50}$ value $(0.73 \mathrm{~g} / 100 \mathrm{~g}$ diet $)$. Seven days following treatment, the efficacy of the tested PCs follows the same trend as previously observed after 2 hours of treatment. $L_{50}$ values reached 0.70 and 1.06 $\mathrm{g} / 100 \mathrm{~g}$ diet with $\mathrm{Ti}$ of 100.0 and $65.91 \%$ for pyrochatechol and resorcinol, respectively.

Also, we determined and compared the glycine content as well as free amino acids in the total body homogenate of $4^{\text {th }}$ instar larvae of PBW treated as newly hatched larvae with $\mathrm{LC}_{50}$ of pyrochatechol and resorcinol and the untreated ones. Results showed that the PCs caused a reduction in the amino acid contents; the most obvious was in resorcinol (the most toxic compound). With audited look for glycine and lysine contents, it could be noted that the pyrochatechol caused an increased while resorcinol caused a lost in the glycine content by $18.56,6.53 \%$, respectively. The loss in the concentration of lysine by resorcinol $(9.09 \%)$ was less than that induced by pyrochatechol (13.40\%). So, the amount of free glycine in PBW appears to have a clear correlation with the detoxification activity of the PCs, especially for the resorcinol. Further study on this phenomenon will give us a chemical basis for understanding how plant-herbivore relationships have evolved.

Keywords: Pectinophora gossypiella, PBW, Lysine, Glycine, protein-denaturing, phenolic compounds, PCs, Cotton plants.
\end{abstract}

\section{INTRODUCTION}

The pink bollworm (PBW), Pectinophora gossypiella (Saund.) assumed to be a major cotton pest. During the course of evolution, plants have developed several chemical defenses against herbivores by accumulating toxic or digestion inhibitory compounds. In insects, several mechanisms used to overcome and detoxify toxic compounds of plants have been found and studied in detail (Dussourd \& Denno, 1991 and Broadway, 1995). 
On the other hand, digestion inhibitory compounds such as phenolic compounds (PCs) are known to denature and decrease the nutritive value of protein. Particularly, dihydroxy phenolics such as chlorogenic acid, caffeic acid, catechol and condensed tannin are chemically active. In an alkaline condition or in the presence of polyphenol oxidase, dihydroxy phenolics are known to be converted into quinones, and these quinones react with the amino residue in the side chain of lysine in protein. As a result, protein is conventional aggregated through the amino residue in the side chain of lysine, and the amount of lysine in denatured protein is decreased (Appel, 1993). Cotton plants produce numerous secondary plant chemicals including PCs (Perveen et al., 2001). Feeny (1970) found that cotton PCs induce a reduction in viability of dietary protein in lepidopterous insects.

However, chemical mechanisms used by insects to overcome protein denaturing compounds, have been studied. A high concentration of free glycine were observed in the midgut content and vomited digestive juice of the silkworm, Bombyx mori, and several other Lepidoptera larvae (Konno et al., 1996). As the amino residue of free glycine is also known to react with PCs in the same manner as the amino residue in the side chain of lysine (Pierpoint, 1969), it is likely that the amino residue of free glycine competes with the amino residue in the side chain of lysine, and therefore inhibits the degenerating and aggregating activity of compounds such as polyphenolics (Konno et al., 2010).

In the present study, we attempted to address two questions. First, we wanted to examine the free amino acid content glycine in PBW. Second, we were interested to answer whether glycine can overcome the cotton PCs and protect PBW or not.

\section{MATERIALS AND METHODS}

The present study has been carried out in the laboratory of Bollworms Department, Plant Protection Research Institute, ARC, Dokki, Giza.

\section{Rearing of $\boldsymbol{P}$. gossypiella:}

Newly hatched larvae of $P$. gossypiella were obtained from a colony maintained in the laboratory for several generations at $27 \pm 1^{\circ} \mathrm{C}$ and $75 \pm 5 \%$ relative humidity (R.H). Larvae were reared on a modified artificial diet as described previously by Abd El-Hafez et al. (1982).

Tested phenolic compounds:

Two phenolic compounds namely; pyrocatechol and resorcinol (Roth: Bestellen sie zum Nulltarif); were used in present study. Figure (1) illustrates the chemical structures of these compounds. According to the results of Ahmed (2007), pyrocatechol and resorcinol proved to be toxic to PBW. For this reason these compounds were chosen for studying the role of glycine as detoxifying agent against cotton PCs in PBW. 
<smiles>Oc1ccccc1O</smiles>

Pyrocatechol

Figure (1): Chemical structures of the tested phenolic compounds

Toxicological studies:

All bioassay trials were tested on the newly hatched larvae of the PBW. Tested materials were homogenate mixed with $100.0 \mathrm{~g}$ of artificial diet to obtain the tested concentrations, i.e.; $0.25,0.5,1.00,1.5$ and $2.00 \mathrm{~g} / 100 \mathrm{~g}$ diet for pyrochatechol and $0.25,0.5,1.00,2.5$ and $4.00 \mathrm{~g} / 100.0 \mathrm{~g}$ diet for resorcinol. After preparation of tested diets, each one was individually folded into 3 Petri dishes $(9 \mathrm{~cm}$ in diameter) as replicates. Ten newly hatched larvae of PBW were placed on the surface of the diet using a soft brush. Another group of 3 Petri dishes was prepared containing the same diet but mixed with equal volume of distilled water (used as control) and an equal number of the maintained larvae were placed on their surface. Larvae were allowed to feed on the tested diets for two hours. Afterwards all alive larvae were transferred individually to glass vials $(2 X 7 \mathrm{~cm})$ containing a small piece of normal diet. Vials were plugged with absorbent cotton and incubated at $27 \pm 1{ }^{\circ} \mathrm{C}$ and $75 \pm$ $5 \% \mathrm{RH}$. Later 2 hours, 2 days and 7 days after treatment all tubes were inspected for mortalities. Percentages of mortalities were corrected according to Abbott's formula (Abbott, 1925) as follows:

$$
\% \text { Correctedmortality }=\frac{\mathrm{T}-\mathrm{C}}{100-\mathrm{C}} \times 100
$$

Where;

$$
\text { T: \%mortality in treatment }
$$

C: \%mortality in check

The corrected mortality percentage of each compound was statistically computed according to Finney (1971), from which the corresponding concentration probit lines (LC-p lines) were estimated. In addition, the efficiency of different compounds was measured by comparing the tested compounds with the most effective compound using toxicity index (Ti) which calculated using the equation of Sun (Sun, 1950) as follows:

$$
\mathrm{Ti}=\frac{\mathrm{LC} 50 \text { of } \mathrm{A}}{\mathrm{LC}_{50} \text { of } \mathrm{B}} \times 100
$$

Where; $\quad$ A: the most effective material
B: the other tested material

\section{Biochemical studies:}

This part of study was conducted in order to determine free amino acids content in the $4^{\text {th }}$ instar larvae of PBW after treatment with tested PCs. 
Newly hatched larvae ( $\approx 100$ larvae) of PBW were allowed to feed on artificial diet containing $L_{50}$ of the two tested PCs, which recorded after two days, for 2 hours and then transferred to feed on control diet. Fourteen days after treatment, the survived $4^{\text {th }}$ instar larvae were collected and refrigerated (at $5^{\circ} \mathrm{C}$ ) for few minutes and then dried in the oven overnight (at $60^{\circ} \mathrm{C}$ ) for biochemical analysis. The total larval bodies were homogenized to get dry powder. Homogenates were weighted and kept till the biochemical determinations.

Amino acid analysis:

Amino acid content was determined as described by Spackman et al. (1958) and Moore et al. (1958). The analysis was performed in Central Service Unit, National Research Center, Egypt, using LC 3000 amino acid analyzer (Eppendorf - Biotronik, Germany). The technique was based on the separation of the amino acids using strong cation exchange chromatography followed by the ninhydrin colour reaction and photometric detection at 570 $\mathrm{nm}$. Samples were hydrolyzed with $6 \mathrm{~N} \mathrm{HCl}$ at $110^{\circ} \mathrm{C}$ in Teflon-capped vials for $24 \mathrm{~h}$. After vacuum removal of $\mathrm{HCl}$, the residues were dissolved in a lithium citrate buffer, $\mathrm{pH}$ 2.2. $20 \mu \mathrm{l}$ of the solution were loaded onto the cation exchange column (pre-equilibrated with the same buffer), then four lithium citrate buffers with $\mathrm{pH}$ values of $2.2,2.8,3.3$ and 3.7 , respectively, were successively applied to the column at flow rate $0.2 \mathrm{ml} / \mathrm{min}$. The ninhydrin flow rate was $0.2 \mathrm{ml} / \mathrm{min}$ at a pressure of 0 to 150 bars. The pressure of buffer was from 0 to 50 bars and reaction temperature was $130^{\circ} \mathrm{C}$.

\section{Statistical analysis}

Toxicological data were statistically calculated through a Proban program, software computer program (Jedrychowski, 1991).

\section{RESULTS AND DISCUSSION}

\section{Insecticidal activities of phenolic compounds}

Table (1) summarizes the concentration-mortality responses of feeding PBW newly hatched larvae for two hours on various concentrations of tested PCs. Data indicated that PCs have great efficacy against PBW larvae. Mortality percentages had a positive relationship with both the concentration and post-treatment period ( $r=0.72 \pm 0.13$ ). Mortality of 20.50 and $79.86 \%$ among PBW newly hatched larvae were achieved within two hours when the lowest $(0.25 \mathrm{~g} / 100 \mathrm{~g}$ diet $)$ and highest $(2.0 \mathrm{~g} / 100 \mathrm{~g}$ diet $)$ concentrations of pyrochatechol were used, respectively. These values increased to 22.98 \& $89.562 \%$ as well as 63.98 and $91.30 \%$ after 2 \& 7 days of treatment, respectively. The lowest concentration $(0.25 \mathrm{~g} / 100 \mathrm{~g}$ diet $)$ of resorcinol caused lower mortality percentages. The values of mortality\% reached $5.44 \%$ after 2 hours of treatment. The values were increased to $33.29 \& 56.00 \%$ after 2 and 7 days, respectively. On the other hand, the highest concentration ( $4 \mathrm{~g} / 100 \mathrm{~g}$ diet) of this PC caused 77.62, $97.55 \& 100.0 \%$ after 2 hours, 2 and 7 days of treatment, respectively. 
Table (1): Efficacy of selected PCs against newly hatched larvae of $P$. gossypiella after 2 hours , 2 days and 7 days of treatment.

\begin{tabular}{|c|c|c|c|c|}
\hline \multirow{2}{*}{\multicolumn{2}{|c|}{ (g/100g diet) Concentration }} & \multicolumn{3}{|c|}{ Corrected mortality (\%) after } \\
\hline & & 2 hours & 2 days & 7 days \\
\hline \multirow{5}{*}{ Pyrochatechol } & 0.25 & 20.50 & 22.98 & 63.98 \\
\hline & 0.50 & 28.89 & 37.97 & 72.65 \\
\hline & 1.00 & 51.72 & 66.03 & 82.74 \\
\hline & 1.50 & 68.93 & 81.56 & 88.09 \\
\hline & 2.00 & 79.86 & 89.56 & 91.30 \\
\hline \multirow{2}{*}{\multicolumn{2}{|c|}{ Correlation $(r) \pm$ S.E. }} & $0.99 \pm 0.07$ (hs) & $0.97 \pm 0.13$ (hs) & $0.96 \pm 0.16$ (hs) \\
\hline & & \multicolumn{3}{|c|}{$0.79 \pm 0.17(\mathrm{hs})$} \\
\hline \multirow{5}{*}{ Resorcinol } & 0.25 & 5.44 & 33.29 & 56.00 \\
\hline & 0.50 & 20.73 & 49.90 & 56.59 \\
\hline & 1.00 & 48.87 & 72.19 & 75.07 \\
\hline & 2.00 & 66.73 & 89.62 & 98.67 \\
\hline & 4.00 & 77.62 & 97.55 & 100.0 \\
\hline \multirow{2}{*}{\multicolumn{2}{|c|}{ Correlation $(r) \pm$ S.E. }} & $0.88 \pm 0.27(\mathrm{~s})$ & $0.88 \pm 0.28$ (ns) & $0.89 \pm 0.27(\mathrm{~s})$ \\
\hline & & \multicolumn{3}{|c|}{$0.75 \pm 0.18$ (hs) } \\
\hline
\end{tabular}

The concentration-mortality relationship of PBW larvae to the PCs was typically expressed as an $L C_{50}$ values (Table 2 ). Based on the $L_{50}$ values, pyrochatechol was the most potent extract after two hours of treatment $\left(\mathrm{LC}_{50}\right.$ reached $1.20 \mathrm{~g} / 100 \mathrm{~g}$ diet with toxicity index $(\mathrm{Ti})=100.0 \%$. On the other hand, resorcinol $\left(\mathrm{LC}_{50}=205.04 \mathrm{~g} / 100 \mathrm{~g}\right.$ diet; $\left.\mathrm{Ti}=95.0 \%\right)$ came next to pyrochatechol in its efficiency against PBW. Two days after treatment, resorcinol became the most effective extract $(\mathrm{Ti}=100.0 \%)$, as it had the lowest $\mathrm{LC}_{50}$ value $(0.73 \mathrm{~g} / 100 \mathrm{~g}$ diet). Seven days following treatment, the efficacy of the tested PCs follows the same trend as previously observed after 2 hours of treatment. $L_{50}$ values reached 0.70 and $1.06 \mathrm{~g} / 100 \mathrm{~g}$ diet with $\mathrm{Ti}$ of 100.0 and $65.91 \%$ for pyrochatechol and resorcinol, respectively.

Table (2): $\mathrm{LC}_{50}(\mathrm{~g} / 100 \mathrm{~g}$ diet) and slope values of selected PCs tested against the newlyhatched larvae of $P$. gossypiella after 2 hours, 2 days and 7 days of treatment.

\begin{tabular}{|l|c|c|c|}
\hline Treatment & \multicolumn{1}{|c|}{$\begin{array}{c}\text { LC } \text { 50 }_{0} \\
\text { Confidence limits (95\%) }\end{array}$} & Slope \pm S.E. & $\begin{array}{c}\text { Toxicity Index\% } \\
\text { (Ti) }\end{array}$ \\
\hline 2 hours after treatment & $\begin{array}{c}1.20 \\
(1.09-1.33)\end{array}$ & $3.06 \pm 0.27$ & 100.0 \\
\hline Pyrochatechol & $\begin{array}{c}205.04 \\
(135.43-326.54)\end{array}$ & $2.616 \pm 0.528$ & 0.590 \\
\hline Resorcinol & $\begin{array}{c}0.86 \\
(0.56-1.26)\end{array}$ & $3.08 \pm 0.52$ & 84.98 \\
\hline 2 days after treatment & $\begin{array}{c}0.73 \\
(0.48-1.06)\end{array}$ & $2.50 \pm 0.34$ & 100.0 \\
\hline Pyrochatechol & $\begin{array}{c}0.70 \\
(0.11-1.69)\end{array}$ & $1.89 \pm 0.51$ & 100.0 \\
\hline Resorcinol & $\begin{array}{c}1.06 \\
(0.99-1.14)\end{array}$ & $6.79 \pm 0.67$ & 65.91 \\
\hline 7 days after treatment & \multicolumn{3}{|l}{} \\
\hline Pyrochatechol & Resorcinol &
\end{tabular}


The effects of PCs on survival of different insect pests have been investigated by several authors. In this respect, Lukefahr \& Martin (1966) reported that only $3 \%$ of the larvae of PBW reached the pupal stage when the diet contained $0.20 \%$ gossypol and $\mathrm{LC}_{90}$ was $0.24 \%$. The results of El-Sayed (1970) also indicated that gossypol affected the number of PBW larvae infested cotton bolls. Zummo et al. (1984) stated that tobacco budworm and cotton bollworm performance was positively correlated with cotton tannin. Guerra et al. (1990) found that the addition of PCs (trans-cinnamic acid, catechol and catechin) to the synthetic diet increased $H$. zea larval mortality. Barbehenn \& Martin (1994) mentioned that Malacosoma disstria is a tannin sensitivity species. On the other hand, Kopper et al. (2002) found that tannin had no detrimental effect on Whitemarked tussock larvae (Lepidoptera: Lymantriidae).

Generally, regarding to the $\mathrm{Ti}$ it could be assumed that pyrocatechol was the most potent compound. Compilation between these results and chemical configurations of PCs (Figure 1) reveals structure-activity relationships. Structural changes may alter the affinity and specificity of binding to particular target sites, and the susceptibility of PCs to metabolism by detoxication systems. The activity of PCs correlates with the number, type, and orientation of the active groups. Higher activity increased with increasing the number of active groups and the occurrence of substitution (hydroxylation, methylation, glycosylation), and with the ortho orientation of active group (Grant \& Langevin, 2002). The present results confirm these findings whereas; pyrocatechol (the most potent compound) have an 0 hydroxyl group. So, the exploration of structure-activity relationships can provide useful insights into the active moiety.

\section{Correlation between concentration of free glycine and resistance to phenolic compounds:}

To test the possibility that the free glycine has a role related to the resistance of the PBW larvae to PCs, we determined and compared the glycine content as well as free amino acids in the total body homogenate of $4^{\text {th }}$ instar larvae treated as newly hatched larvae with LC $_{50}$ (recorded after 2 days) of pyrochatechol and resorcinol and $4^{\text {th }}$ instar larvae of the untreated PBW (Table 3 \& Figure 2).

Generally, results showed that the PCs caused a reduction in the amino acid contents and the effect of resorcinol (the most toxic compound after 2 days) was the most obvious. With audited look for glycine and lysine contents, it could be noted that the pyrochatechol caused an increase while resorcinol caused a lost in the glycine content by $18.56 \& 6.53 \%$, respectively. The loss in the concentration of glycine by resorcinol $(9.09 \%)$ was less than that induced by pyrochatechol $(13.40 \%)$. It could be due to inhibition of the decrease in lysine caused by this PC (Konno et al., 2009). So, in our model glycine is assumed to be lost by binding to PCs, but this loss is less detrimental for herbivores than the loss of lysine. The larvae might be spending glycine, which is a nonessential amino acid, to save lysine, which is essential and a more precious amino acid. So, the amount of free glycine in PBW appears to have a clear correlation with the detoxification activity of the PCs, especially for the resorcinol. 
Also, it could be noted that pyrochatechol increased the concentration of glycine, alanine \& proline (nonessential amino acids) and methionine (essential amino acid). On the other hand the reduction in the histidine (semiessential amino acid) and lysine (essential amino acid) by pyrochatechol was higher than that induced by resorcinol. With previous observations it could be noted that other free amino acids may be used by some herbivores as counteractive agents against the denaturing activity of oxidized phenolics (konno et al., 2010).

Table (3): Concentration of free amino acids $(\mu \mathrm{g} / \mathrm{ml})$ in the total body homogenateof $P$. gossypiella $4^{\text {th }}$ instar larvae.

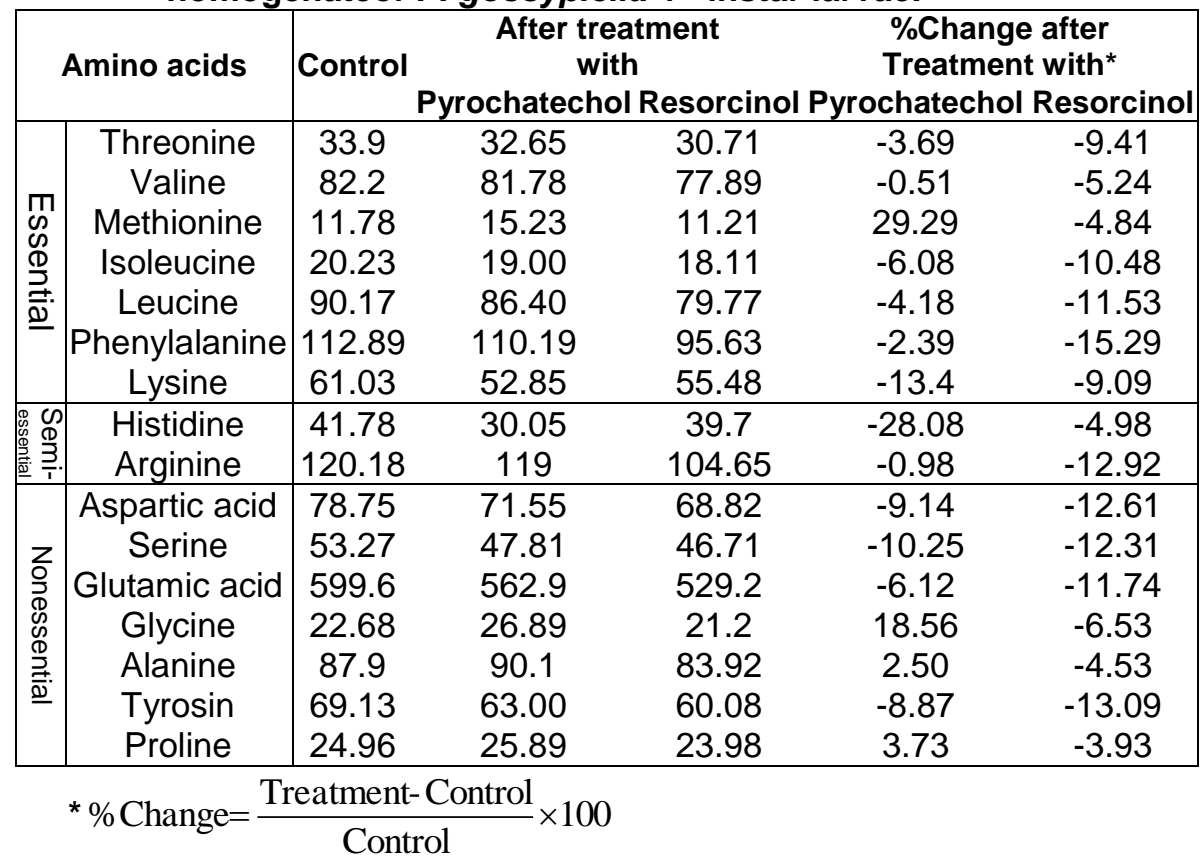



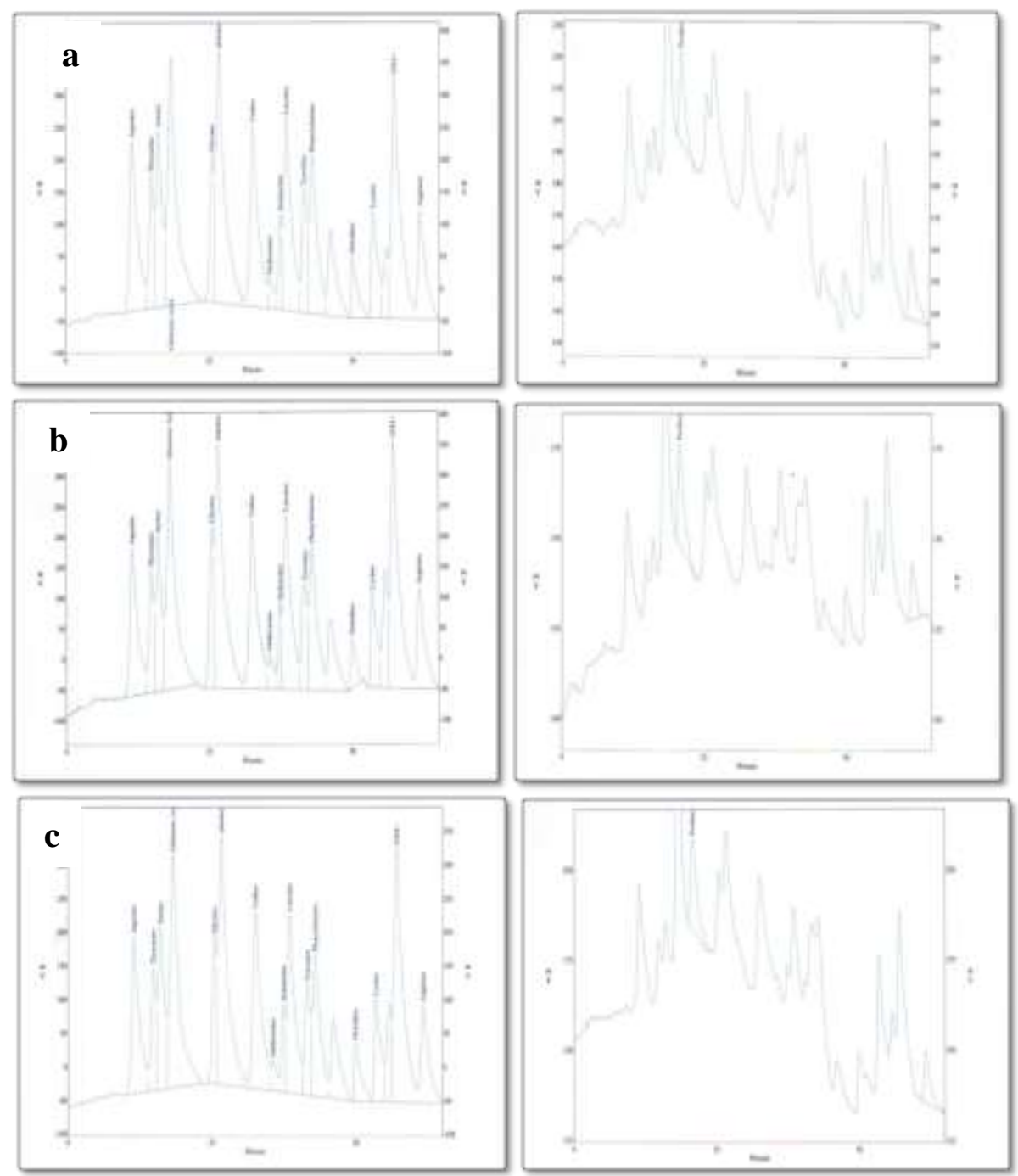

Figure (2): The composition of free amino acids in the total body homogenate of $P$. gossypiella $4^{\text {th }}$ instar larvae (a) control (b) pyrochatechol-treated (c) resorcinol-treated.

To our knowledge, this is the first demonstration that such a simple molecule as glycine can work as, and is actually used by PBW as, a counteracting agent against protein denaturing activity of plant PCs which is found in cotton plants since cotton plants contain PCs. Further study on this phenomenon will give us a chemical basis for understanding how plant-herbivore relationships have evolved. 


\section{REFERENCES}

Abbott, W.S. (1925): A method of computing the effectiveness of an insecticide. J. Econ. Entomol. 18: 265-267.

Abd El-Hafez, Alia; Metwally, A.G. and Saleh, M.R.A. (1982): Rearing pink bollworm Pectinophora gossypiella (Saund.) on kidney bean diet in Egypt. Res. Bull., Fac. Agric., Zagazig Univ. 576: 1-10.

Ahmed, Dina A. (2007): Biochemical and toxicological studies on the effect of some plant extracts on pink bollworm, Pectinophora gossypiella (Saunders), in relation to their phenolic contents. Ph.D. Thesis, Faculty of Agriculture, Cairo University.

Appel, H. M. (1993); Phenolics in ecological interactions: the importance of oxidation. J. Chem. Ecol. 19: 1521-1552.

Barbehenn, R.V. and Martin, M.M. (1994): Tannin sensitivity in larvae of Malacosoma disstria (Lepidoptera): roles of the peritrophic envelope and midgut oxidation. J. Chem. Ecol., 20: 1985-2001.

Broadway, R.M. (1995): Are insects resistant to plant proteinase inhibitor?. J. Insect Phvsiol. 41: 107-116.

Dussourd, D.E. and Denno R.F. (1991): Deactivation of plant defense: correspondence between insect behavior and secretary canal architecture. Ecology. 11: 1383-1396.

El-Sayed, N.A.R. (1970): The relation between the gossypol content of cotton varieties and its toxicity to insects. M.Sc. Thesis, Faculty of Agiculture, Cairo University, Egypt.

Feeny,P.(1970):Seasonal changes in oak leaf tannins and nutrients as a cause of spring feeding by winter moth caterpillars. Ecology.51:565581.

Finney, D. J. (1971): Probit-analysis, $3^{\text {rd }}$ Ed., Cambridge University Press, London.

Grant, G.G. and Langevin, D. (2002): Structure-activity relationships of phenolic and nonphenolic aromatic acids as oviposition stimuli for the spruce budworm, Choristoneura fumiferana (Lepidoptera: Tortricidae). Use of pheromones and other semiochemicals in integrated production. IOBC wprs Bulletin Vol. 25: 1-10. http://phero.net/iobc/samos/bu lletin/grant.pdf.

Guerra, D.J.; Cothren J.T. and Phillips, J.R. (1990): Influence of selected phenolic compounds on development of bollworm (Lepidoptera: Noctuidae) larvae. J. Econ. Entomol. 83: 2115-2118.

Jedrychowski, R.A. (1991). Proban software program, version 1.1.

Konno, K.; Hirayama, C. and Shinbo, H. (1996): Unusually high concentration of free glycine in the midgut content of the silkworm, Bombyx mori and other lepidopteran larvae. Comp. Biochem. Physiol., 115A: 229-235.

Konno, K.; Hirayama, C.; Shinbo, H. and Nakamura, M. (2009): Glycine addition improves feeding performance of non-specialist herbivores on the privet, Ligustrum obtusifolium: In vivo evidence for the physiological impacts of anti-nutritive plant defense with iridoid and insect adaptation with glycine. Appl. Entomol. Zool. 44 (4): 595-601. 
Konno, K.; Hirayama, C.; Yasui, H.; Okada, S.; Sugimura, M.; Yukuhiro, F.; Tamura, Y.; Hattori, M.; Shinbo, H. and Nakamura, M. (2010): GABA, $\beta$-Alanine and glycine in the digestive juice of privet-dpecialist insects: convergent adaptive traits against plant iridoids. J. Chem. Ecol. 36: 983-991.

Kopper, B.J.; Jakobi, V.N.; Osier, T.L. and Lindroth, R.L. (2002): Effects of paper birch condensed tannin on Whitemarked tussock moth (Lepidoptera: Lymantriidae) performance. Environ. Entomol., 31: 10-14.

Lukefahr, M.J. and Martin, D.F. (1966): Cotton pigments as a source of resistance to the bollworm and tobacco budworm. J. Econ. Entomol. 59: 176-179.

Moore, S. Spackman, D.H. and Stein, W.H. (1958). Chromatography of amino acids on sulphonated polystyrene resins: An improved system. Anal. Chem. 30: 1185-1190.

Perveen, S.S.; Qaisrani, T.M.; Bhutta, S.; Perveen R. and Naqvi, S.H.M. (2001): HPLC analysis of cotton phenols and their contribution in bollworm resistance. OnLine Journal of Biological Sciences. 1 (7): 587 590. $h$ ttp//www.pjbs.org/ansinet/ojbs/journal/2001/toc1(7).

Pierpoint, W.S. (1969): o-Quinones formed in plant extracts, their reactions with amino acids and peptides. Biochem. J. 112: 609-616.

Spackman, D.H.; Stein, W.H. and Moore, S. (1958): Automatic recording apparatus for use in chromatography of amino acid. Anal. Chem. 30: 1190-1206.

Sun, Y.P. (1950). Toxicity index on improved method of comparing the relative toxicity of insecticides. J. Econ. Entomol. 43: 45-53.

Zummo, G.R.; Segers, J.C. and Benedict, J.H. (1984): Seasonal phenology of allelochemicals in cotton and resistance to bollworm (Lepidoptera: Noctuidae). Environ. Entomol. 13 (5): 1287-1290. 
دور الحمض الأميني الجليسين في حمايـة دودة اللوز القرنفلية من التأثير المثبط

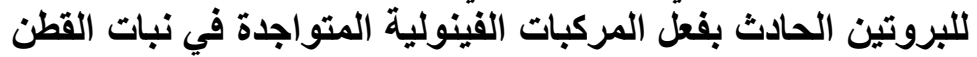

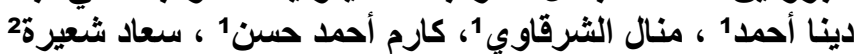

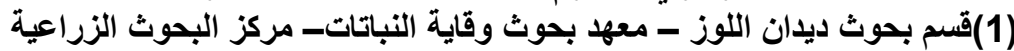

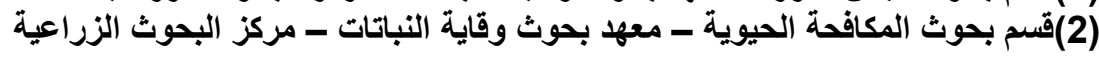

ثبت من خلال الدراسات أن عديد من حرشفيات الأجنحة خاصة تلك التي تعيش علي عو ائل

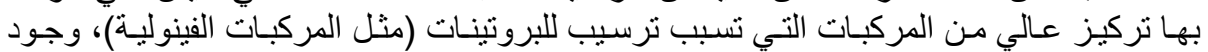

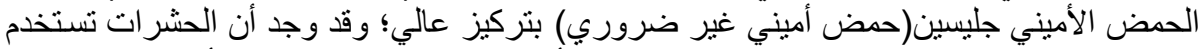

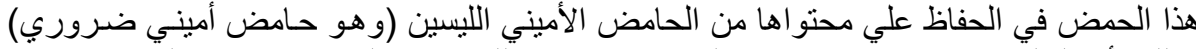

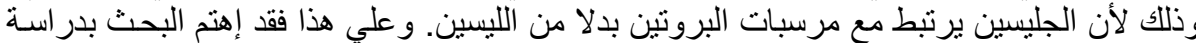

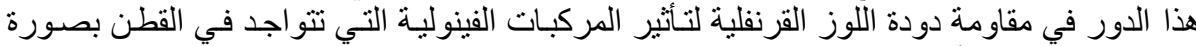

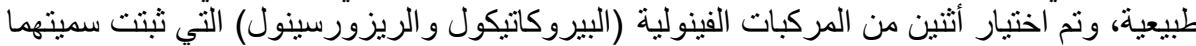

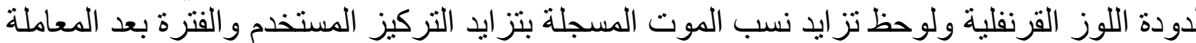

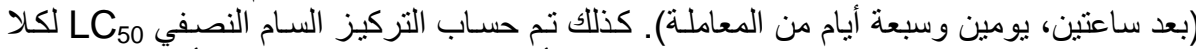

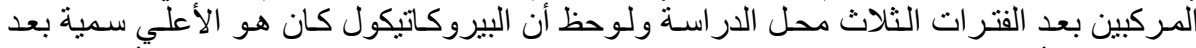

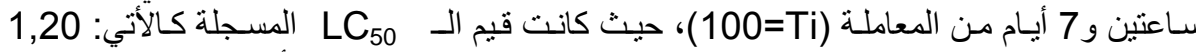

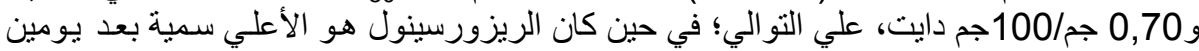

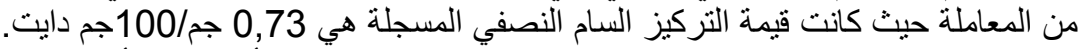

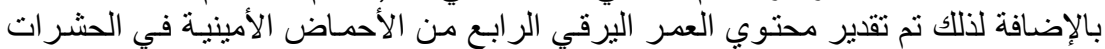

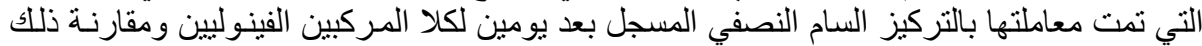

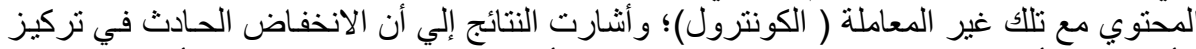

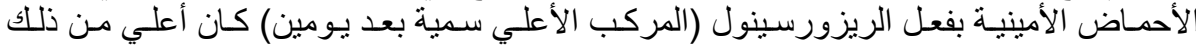
الانخفاض الحادث بفعل البيروكاتيكول.

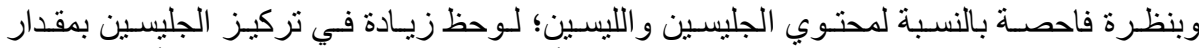

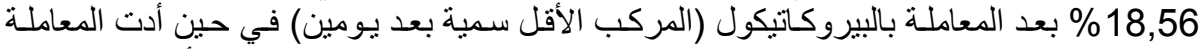

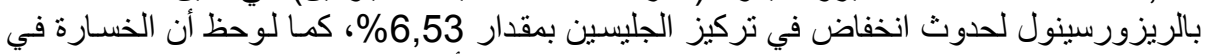

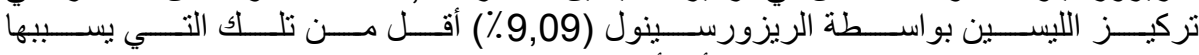

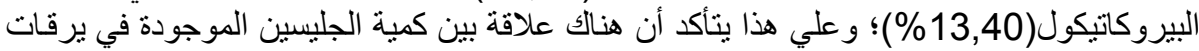

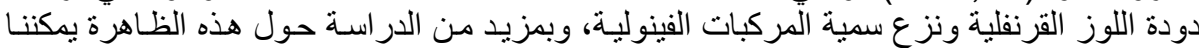
التوصل لفهم الأساس الكيميائي لنطور العلاقة بين النبات والحشر التشرات. 
Dina A. Ahmed et al.

Dina A. Ahmed et al.

Dina A. Ahmed et al.

Dina A. Ahmed et al.

Dina A. Ahmed et al.

Dina A. Ahmed et al.

Dina A. Ahmed et al.

Dina A. Ahmed et al.

Dina A. Ahmed et al.

Dina A. Ahmed et al.

Dina A. Ahmed et al.

Dina A. Ahmed et al.

Dina A. Ahmed et al.

Dina A. Ahmed et al.

Dina A. Ahmed et al.

Dina A. Ahmed et al.

Dina A. Ahmed et al.

Dina A. Ahmed et al.

Dina A. Ahmed et al.

Dina A. Ahmed et al.

Dina A. Ahmed et al.

Dina A. Ahmed et al.

Dina A. Ahmed et al.

Dina A. Ahmed et al.

Dina A. Ahmed et al.

Dina A. Ahmed et al.

Dina A. Ahmed et al.

Dina A. Ahmed et al. 
J. Plant Prot. and Path., Mansoura Univ., Vol. 5 (12), December, 2014

Dina A. Ahmed et al.

1065 